\title{
Are signs of burnout and stress in palliative care workers different from other clinic workers?
}

\author{
Palyatif bakım çalışanlarında tükenmişlik ve stres belirtileri diğer klinik çalışanlarında farklı mı?
}

\section{Oktay Faysal TERTEMIZ, ¿ Emel TÜYLÜOĞLU}

\begin{abstract}
Summary
Objectives: Palliative care workers have continuous exposure to the emotionally draining effects of pain, suffering, death, grief, and mourning. Burnout syndrome is common among these individuals who accompany patients on the way to death. This study evaluated burnout, stress, anxiety, and depression among care givers.

Methods: A total of 47 individuals working in palliative care units or internal disease and neurology clinics participated in the study. The participants were divided into 2 groups: palliative care workers (Group P) and workers in internal disease and neurology clinics (Group A). All of the participants completed the Maslach Burnout Inventory, the Beck anxiety and depression scales, and the Stress Appraisal Measure.

Results: A total of 47 healthcare workers agreed to complete the scales. Emotional burnout and desensitization scores were found to be elevated, and personal success scores were low in both groups. The Beck Anxiety Inventory revealed findings of moderate anxiety in both groups, while cognitive-sensorial, physiological, and pain complaints, as well as signs of stress, were more pronounced in Group A.

Conclusion: Burnout is a significant problem among healthcare workers and signs of stress and cognitive-sensorial, physiological, and pain complaints are particularly common among those working in palliative care units. Structural arrangements aimed at addressing the causes of burnout could positively affect the well-being of healthcare workers.
\end{abstract}

Keywords: Beck Anxiety Inventory; burnout; Maslach Burnout Inventory; palliative care; Stress Appraisal Measure.

\section{Özet}

Amaç: Palyatif bakım çalışanları acı, ızdırap, ölüm, keder, yas gibi yükü ağır kavramlarla sürekli temas halindedir. Palyatif çalışanlarında bakım süreçlerine eşlik etmeleri nedeniyle tükenmişlik sendromunun görülmesi daha sıktır.

Gereç ve Yöntem: Çalışmaya palyatif bakım çalışanları ile dahiliye ve nöroloji servisi çalışanları olarak toplam 47 kişi katıldı. Katılımcılar palyatif bakım çalışanları (Grup P) ve dahiliye ve nöroloji servisinde çalışanlar (Grup A) kabul edildi. Çalışmaya katılanlara Maslach tükenmişlik ölçeği, BECK anksiyete depresyon ölçeği ve Stres Belirtiler Ölçeği kullanıldı.

Bulgular: Kırk yedi sağlık çalışanı ölçekleri doldurmayı kabul etti. Her iki grupta da duygusal tükenme ve duyarsızlaşma puanı yüksek, kişisel başarı puanı ise düşük olarak bulundu. BECK anksiyete depresyon ölçeğine göre orta düzeyde anksiyete bulgusu mevcuttu. Ancak bilişsel-duyusal, fizyolojik ve ağrı yakınmaları ile stres belirtileri Grup A'da daha yüksekti.

Sonuç: Tükenmişlik, sağlık çalışanlarının karşı karşıya olduğu önemli bir sorundur. Özellikle palyatif bakım biriminde çalışan sağlık personelinde stres belirtileri ile bilişsel-duyusal, fizyolojik ve ağrı yakınması daha fazladır. Tükenmişlik nedenlerinin düzeltilmesine yönelik yapısal düzenlemeler yapılması çalışan sağlığını olumlu etkileyecektir.

Anahtar sözcükler: Beck Anksiyete Ölçeği; tükenmişlik; palyatif bakım; Maslach Tükenmişlik Envanteri; Stres Değerlendirme Ölçeği.

\section{Introduction}

The continuous face-to-face interactions between healthcare workers and patients require additional emotional and physical capabilities, and this may have various challenging effects on healthcare workers. This is particularly important among healthcare providers working in palliative care units where the quality of life of patients is a primary concern. The main aim of palliative care is to build close relations with the patients and their relatives, and to ease their physical and emotional symptoms. ${ }^{[1]}$ The holistic nature of palliative care (along with the psychosocial, physical and spiritual dimensions) requires gaining knowledge and abilities to deal with such factors as

\section{Department of Playatif Care, Balıkesir Atatürk State Hospital, Balıkesir, Turkey}

Submitted (Başvuru tarihi) 03.07.2018 Accepted after revision (Düzeltme sonrası kabul tarihi) 23.09.2019 Available online date (Online yayımlanma tarihi) 26.02.2020

Correspondence: Dr. Oktay Faysal Tertemiz. Balıkesir Atatürk Devlet Hastanesi, Palyatif Bakım Servisi, Balıkesir, Turkey. 
death and grief. ${ }^{[2]}$ As the number of patients requiring palliative care increases day by day, the challenges and stress experienced by healthcare workers grows even larger, and this leads to physical, psychological and emotional challenges among healthcare workers that if left untreated, may result in burnout. ${ }^{[3]}$ Burnout syndrome was first described by Herbert Freudenberg ${ }_{1}^{[4]}$ and Maslach and Leiter later extended the description to define three dimensions of burnout, being: emotional burnout, desensitization and lack of personal success in the workplace. ${ }^{[5]}$ In addition to the negative effects on the professional, family and social lives of workers, burnout syndrome can also have negative consequences on physical health, and in this regard, it represents a social and economic problem that is associated with high costs. This syndrome is particularly common among healthcare professionals working in clinics with a high rate of mortality. ${ }^{[6]}$ Negative effects have been reported in nurses who provide care to moribund patients, who have reported feeling unprepared, particularly due to a lack of knowledge. ${ }^{[7]}$ Burnout is one of the most common problems among healthcare providers working in oncology clinics, and managers of oncology units should be aware of the potential for the development of burnout syndrome among their workers. ${ }^{[8]}$

The Maslach Burnout Inventory evaluates burnout in three dimensions, including Emotional burnout (EB), reflecting personal overload; desensitization (DS), defined as an insensitive and careless approach to those in care; and personal success (PS), related to the sufficiency and success in problem solving. ${ }^{[9]}$ The Maslach Burnout Inventory consists of 22 questions, with answers reported on a scale of $0-4 .{ }^{[10]}$ The validity and reliability of the Turkish scale havebeen demonstrated previously. ${ }^{[11]}$ The BECK anxiety depression scale is used to determine the frequency of anxiety signs. There are 21 categories of signs, each consisting of four options, and each item is scored on a scale of $0-3 .{ }^{[12]}$ The Turkish adaptation of the scale has been assessed, and validated. ${ }^{[13]}$ The Stress Appraisal Measure (SAM) is a four-item Likert-type measurement tool consisting of 38 questions ( $1=$ Never, $2=$ Occasionally, $3=$ Frequently, 4=Always). Based on a factor analysis performed by Hovardaoglu, the scale assesses three factors: cognitive-sensorial, physiological and pain complaints. ${ }^{[14]}$
The present study aimed to reveal the differences in the signs of burnout and stress between palliative care workers and those working in neurology and internal disease clinics.

\section{Materials and Methods}

The study was initiated after approval was obtained from the local ethics committee (registration no: 2017/103), and was conducted as a single-center study including individuals aged between 18 and 60 years, who were employees in the palliative care units, internal disease clinics or neurology clinics of Balikesir Ataturk City Hospital. All subjects participating in the study provided written informed consent. Those who refused to participate in the study, those who worked in the relevant clinics for less than two months, and physicians were excluded from the study. The study included nurses, midwifes, housekeeping personnel and healthcare personnel. Physicians responsible for palliative care were excluded from the study, as they were involved in the planning of the study. Data regarding the age, gender, profession, years at work and regular medication use of the participants was recorded.

The subjects participating in the study were divided into two groups. Group P included palliative care workers, and Group A consisted of workers in the internal disease and neurology clinics. The subjects who agreed to participate in the study completed the Maslach burnout inventory, the BECK anxiety depression scale and SAM. The Group P consists of 25 personnel and Group A consists of 22 personnel.

The statistical analysis was performed using SPSS for Windows Release 22.0 software. Qualitative data was compared with a Chi-Square test, and parametric data was checked for normal distribution with a Kolmogorov-Smirnoff test. Normally distributed data was compared with a Student t-test, and a Mann-Whitney U-test was used to compare the abnormally distributed data. A repeated measures variance analysis or Friedman test was used to compare measurements recorded continuously from the baseline. Parametric data was presented as mean and standard deviations, and non-parametric data was presented as percentages (\%). P values of $<0.05$ were considered statistically significant. 


\section{Results}

In total, 47 healthcare workers were included in the study. In Group P, five of the 30 workers refused to participate in the study, while all workers in Group A agreed to participate. The participants were given no direction; no interventionswas made and they were allowed to complete the questionnaires on their own.

The mean age, gender distribution, duration of employment in relevant clinics and medication use were not significantly different between the two groups (Table 1). In total, three individuals in Group $P$ and two individuals in Group A were taking antidepressants. Of the 25 subjects in Group P, four were housekeeping personnel, six were midwives, eight were nurses and seven were caregivers, while Group A included four housekeeping personnel, $10 \mathrm{mid}-$ wives and eight nurses.

The mean EB, DS and PS scores measured from the Maslach Burnout Inventory were not statistically significantly different between the two groups. The mean EB, DS and PS scores in Group P were 30 \pm 9 , $11 \pm 4$ and $30 \pm 5$, respectively, and in Group $A$, the mean EB, DS and PS scores were $33 \pm 8,10 \pm 3$ and $30 \pm 4$, respectively.There were no statistically significant differences between the two groups.

The mean scores from the BECK anxiety depression scale in Group P and A were $19 \pm 12$ and $17 \pm 11$, respectively, and was not statistically significant.

Among the factors measured by SAM, the cognitivesensorial complaint scores were $30 \pm 8$ and $25 \pm 6$, the physiologic complaint scores were $18 \pm 4$ and $15 \pm 3$, and the pain complaint scores were $17 \pm 4$ and $14 \pm 3$, in Groups $P$ and $A$, respectively. The total scores of SAM were calculated as $74 \pm 18$ and $62 \pm 13$ in Groups $P$ and $A$, respectively. The cognitive-sensorial, physiological and pain complaint scores and the overall SAM score were significantly higher in Group P than in Group A (Fig. 2).

\section{Discussion}

EB scores were elevated and DS scores were at moderate level in both groups of workers, and the differences were not statistically significant. PS scores, on the other hand, were found to be increased in both groups. The scores of the BECK anxiety depression
Table 1. Demographic data

\begin{tabular}{lccc}
\hline & Group P & Group A & p \\
\hline Age (years) (Mean \pm SD) & $37 \pm 8$ & $36 \pm 8$ & 0.805 \\
Sex (F/M) & $23 / 2$ & $20 / 2$ & 0.897 \\
Study time (month) & 64 & 56 & 0.600 \\
Drug users & 3 & 2 & 0.751 \\
\hline
\end{tabular}

SD: Standard deviation.

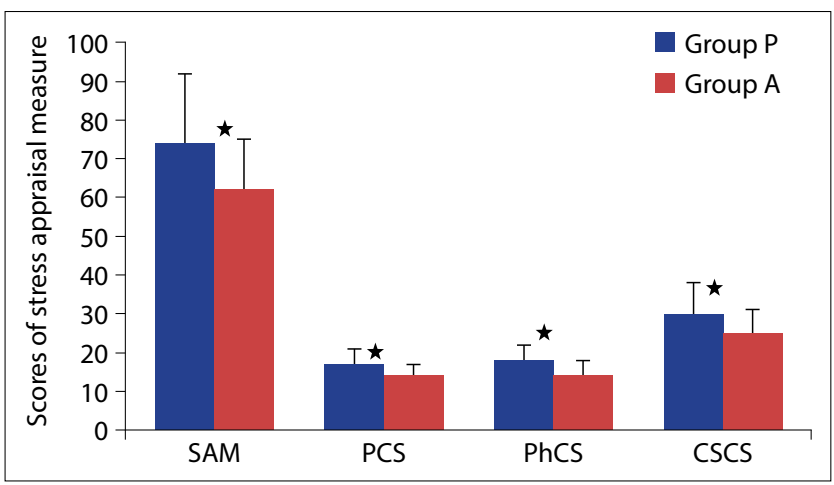

Figure 1. Comparison of total score of SAM, and scores for cognitive-sensorial, physiological and pain complaints between the two groups.

Group P: Palliative care unit workers; Group A: Workers in internal diseases and neurology clinics; SAM: Stress appraisal measure total score; PCS: Pain complaint score; PhCS: Physiological compliant score; CSCS: Cognitive-sensorial complaint score; mean $\pm \mathrm{SD} ;{ }^{*} \mathrm{p}<0.05$.

scale indicated a moderate level of anxiety in both groups, while cognitive-sensorial, physiologic and pain complaints, as well as signs of stress, were more pronounced among the palliative care workers.

Burnout is generally considered to be a syndrome that presents with emotional burnout, desensitization and a decrease in the sense of personal success. ${ }^{[5]}$ Workers suffering from burnout and a lack of compassion may have a negative influence in units providing care to patients who require compassionate care, and this may result in symptoms of emotional burnout anddecreases in job performance. ${ }^{[1]}$

Signs of burnout, which can manifest as interpersonal sensitivity, depression, hostility and paranoid thoughts are common among healthcare professionals. Global Severity Index and Positive Symptom Total index scores among healthcare workers was elevated. ${ }^{[15]}$ Burnout syndrome may lead to such physical symptoms as chronic exhaustion and gastrointestinal complaints; emotional signs like apathy, desensitization and irritability; social effects, such as isolation and loss of interest in previously enjoyed activities; an absence of spiritual 
awareness; reluctance to provide care to certain patients, a reduced willingness to come to work and low performance. ${ }^{[16]}$

Due to the increase in life expectancy with medical improvements, the number of patients with advanced incurable diseases is continuously on the rise, which increases the need for palliative care. ${ }^{[3]}$ The expectations and demands from healthcare providers can be rather high in palliative care units, and the risk of burnout is known to be higher in workers interacting with moribund patients. ${ }^{[17]}$ Rizo-Baeza reported previously that working for more than eight hours a day, having a single parent, moderate or high levels of workload, occupational quality of life deficiency and low level of self-care were factors that increase the prevalence of burnout syndrome among palliative care workers. ${ }^{[6]}$ Psychological, emotionaland spiritual relief is also decreased if the workers perceive their workplace as being over-challenging and demanding. ${ }^{[3]}$ Previously reported incidences of burnout syndrome among palliative care workers have varied between 16 and $62 \%$ in literature, ${ }^{[18,19]}$ and this wide range may be attributed to differences in the investigated sub-groups, working conditions and cultural differences.

Görgülü et al. Examined the burnout levels of all the staff of the hospital (doctors, nurses, contract staff, cleaning, cooking, and maintenance). The EB is 25.79 , the DS is 11.40 , PS is 24.30 calculated. ${ }^{[20]}$ The scores in our study were higher than in this study. This shows that burnout is more severe. A correlation has been identified between emotional overload and the BECK depression scale. ${ }^{[21]}$

In the present study, signs of burnout were noted in both groups, although the scores of cognitivesensorial complaints, physiologic complaints, pain complaints and total scores obtained from SAM were found to be increased among palliative care workers. Moreover, according to the BECK AnxietyDepression Scale, signs of moderate anxiety were present in both palliative care workers and the workers in internal disease and neurology clinics.

In a study comparing the level of burnout among intensive care unit and palliative care unit workers found higher levels of burnout among intensive care unit personnel. Additionally, the risk of burnout among palliative care personnel was found to be lower than among intensive care unit personnel. ${ }^{[18]}$

While the reduced level of desensitization was a rather positive finding of thisstudy, the same cannot be said for emotional burnout. The difference in these findings may be attributable to the differences in cultural values and judgments, as well as the personal lives of the participants or their working conditions. The relatively high scores in personal success, on the other hand, may be related to the willingness of the workers to carry out their jobs and their selfperception as being successful.

Moreover, the fact that palliative care workers provide care to patients with various long-term and difficult-to-treat diseases in the fields of internal diseases and neurology may have led to the similar Maslach and BECK results, and these outcomes may also be affected by the continuous on-the-job training and experience-sharing meetings undertaken by palliative care workers.

The causes and outcomes of burnout should be evaluated on an individual basis, and personnel who experience burnout should be supported both institutionally and personally. Patient-specific treatment should be planned that may include stress management, medical treatment or psychotherapy.

In addition to these options, regular training andmedical treatments are applied in our hospital; whereas Cognitive Behavioral Therapy (CBT) and EMDR (Eye Movement Desensitization and Reprocessing) have not been tried to date. For the following steps, studies can be planned to reduce burnout and stress through EMDR.

Despite the negative findings, it was satisfying to note that personal success scores were high in this study, and this may be attributable to the fact that the study participants performed their jobs with compassion and considered themselves successful.

This study has a number of limitations. First of all, the number of subjects included in this study was limited, and they may provide biased answers when filling out thequestionnaires. That said, this may have little influence on the findings, as the questionnaires were not applied during face-to-face interviews. Ad- 
ditionally, this study did not categorize the participants based on their occupations, meaning thatthe burnout levels of nurses and other healthcare workers were not evaluated separately. Moreover, different results would likely be obtained if palliative care workers were compared with workers in other clinics, or with staff who provide care to patients in different clinics.

\section{Conclusion}

Signs of burnout were to be high in workers in both internal diseases and neurology service departments and in palliative care workers. Signs of stress were also more common in these groups when compared to workers in other departments. The elevated levels of stress among palliative care workers highlights a need to provide stress management for this personnel group.

It is obvious that employment in palliative care units can have a negative effect on the personnel working in this field, as well as the patients. Palliative care workers should be part of a structure in which emotional and cognitive awareness are increased, where they can express their feelings and recognize that they have control. Symptoms of burnout can be reduced by supporting teamwork,ensuring commitment within teams,building a regularly working system for conflict management, recognizing the importance of personal development and rest,and providing a sufficient level of high-quality communication. In this regard, it is obvious that regular training and experience-sharing meetings can provide significant benefits to such workers.

Ethics Committee Approval: The Balıkesir University Faculty of Medicine Clinical Research Ethics Committee granted approval for this study (date: 01.11.2017, number: 2017/103).

Conflict-of-interest issues regarding the authorship or article: None declared.

Financial Disclosure: The authors declared that this study has received no financial support.

Peer-rewiew: Externally peer-reviewed.

\section{References}

1. Linzitto JP, Grance G. Health professionals' quality of life in relation to end of life care. Curr Opin Support Palliat Care 2017;11(4):306-9. [CrossRef]
2. O'Mahony S, Gerhart Jl, Grosse J, Abrams I, Levy MM. Posttraumatic stress symptoms in palliative care professionals seeking mindfulness training: Prevalence and vulnerability. Palliat Med 2016;30(2):189-92. [CrossRef]

3. Parola V, Coelho A, Cardoso D, Gea-Sanchez M, BlancoBlanco J, Apóstolo J. The prevalence of burnout in health professionals working in palliative care: a systematic review protocol. JBI Database System Rev Implement Rep 2016;14(3):45-50. [CrossRef]

4. Freudenberger HJ. Staff burn-out. J Soc Issues 1974;30(1): 159-65. [CrossRef]

5. Maslach C, Leiter MP. The truth about burnout: how organizations cause personal stress and what to do about it. 1st ed. San Francisco, CA: Jossey-Bass; 1997.

6. Rizo-Baeza M, Mendiola-Infante SV, Sepehri A, Palazón-Bru A, Gil-Guillén VF, Cortés-Castell E. Burnout syndrome in nurses working in palliative care units: An analysis of associated factors. J Nurs Manag 2018;26(1):19-25. [CrossRef]

7. Andersson $E$, Salickiene $Z$, Rosengren $K$. To be involved - A qualitative study of nurses' experiences of caring for dying patients. Nurse Educ Today 2016;38:144-9. [CrossRef]

8. Cañadas-De la Fuente GA, Gómez-Urquiza JL, OrtegaCampos EM, Cañadas GR, Albendín-García L, De la Fuente-Solana El. Prevalence of burnout syndrome in oncology nursing: A meta-analytic study. Psychooncology 2018;27(5):1426-33. [CrossRef]

9. Oğuzberk, M., Aydın A. Ruh Sağlık Çalışanlarında Tükenmişlik, Klinik Psikiyatri 2008;11:167-79.

10. Sayıl I, Haran S, Ölmez Ş, Devrimci Özgüven H. Ankara Üniversitesi Hastanelerinde Çalışan Doktor ve Hemşirelerin Tükenmişlik Düzeyleri. Kriz Dergisi 1997;5(2):71-7.

11. Ergin C. Doktor ve hemşireler de tükenmişlik ölçeğinin uyarlanması. In: Bayraktar R, Dağ I, editors. VII. Ulusal Psikoloji Kongresi Bilimsel Çalışmaları. Türk Psikologlar Derneği 1992. p. 143-54.

12. Beck AT, Epstein N, Brown G, Steer RA. An inventory for measuring clinical anxiety: psychometric properties. J Consult Clin Psychol 1988;56(6):893-7. [CrossRef]

13. Hisli N. Beck Depresyon Envanteri'nin geçerliği üzerine bir çalışma. Türk Psikoloji Dergisi 1988;6:118-26.

14. Hovardaoglu, S. Stres Belirtileri İle Durumsal ve Sürekli Kaygının Yordanması. Kriz Dergisi 1997;5(2):127-34.

15. Fernández-Sánchez JC, Pérez-Mármol JM, Blásquez $A$, Santos-Ruiz AM, Peralta-Ramírez MI. Association between burnout and cortisol secretion, perceived stress, and psychopathology in palliative care unit health professionals. Palliat Support Care 2018;16(3):286-97. [CrossRef]

16. Boyle DA. Compassion fatigue: The cost of caring. Nursing 2015;45(7):48-51. [CrossRef]

17. Pavelková $H$, Bužgová R. Burnout among health care workers in hospice care. Cent Eur J Nurs Midw 2015;6(1):21823. [CrossRef]

18. Martins Pereira S, Teixeira CM, Carvalho AS, HernándezMarrero P; InPalln. Compared to Palliative Care, Working in Intensive Care More than Doubles the Chances of Burnout: Results from a Nationwide Comparative Study. PLoS One 
2016;11(9):e0162340. [CrossRef]

19. Kamal AH, Bull JH, Wolf SP, Swetz KM, Shanafelt TD, Ast K, et al. Prevalence and Predictors of Burnout Among Hospice and Palliative Care Clinicians in the U.S. J Pain Symptom Manage 2016;51(4):690-6. [CrossRef]

20. Gorgulu O, Akilli A. The determination of the levels of burnout syndrome, organizational commitment, and job satisfaction of the health workers. Niger J Clin Pract 2017;20(1):48-56. [CrossRef]

21. Vasconcelos EM, Martino MMF, França SPS. Burnout and depressive symptoms in intensive care nurses: relationship analysis. [Portuguese] Rev Bras Enferm 2018;71(1):135-41. 